Thomsen, H. H. 1984a: Glaciologiske undersøgelser i Disko Bugt området 1983. Grønlands geol. Unders., Gletscher-hydrol. Meddr 83/8, 24 pp.

Thomsen, H. H. 1984b: Glaciological reconnaissance, mass balance measurements and mapping programmes in connection with Greenland hydropower. Rapp. Grønlands geol. Unders. 120, 95-99.

Thomsen, H. H. 1985: Glaciological field work and remote sensing in connection with hydropower investigations, West Greenland. Rapp. Grønlands geol. Unders. 125, 95-99.

Thomsen, H. H. \& Madsen, P. S. 1985: Radio ekko målinger af Indlandsisens randzone i Disko Bugt området 1984. Grønlands geol. Unders., Gletscher-hydrol. Meddr 85/1, 20 pp.

Weidick, A. 1968: Observations on some Holocene glacier fluctuations in West Greenland. Bull. Grønlands geol. Unders. 73 (also Meddr Grønland 165,(6) 202 pp.).

\title{
Stable isotope studies on the Greenland ice-sheet margin
}

\author{
Niels Reeh and Henrik Højmark Thomsen
}

Stable isotope analysis has been used intensively in the investigation of snow and ice-cores retrieved from the central region of the Greenland ice sheet. The $\delta^{18} \mathrm{O}$ records from the deep ice cores drilled at Camp Century and Dye 3, for example, provided detailed climatic information for the past maybe more than 100000 years (Dansgaard et al., 1985). However, although the marginal zone of the ice sheet is readily accessible compared with the central region, little attention has been given to stable isotope studies in the marginal zone (the ablation zone).

\section{Sampling programme}

To provide a background to evaluate stable isotope methods for studying the hydrology and dynamics of the marginal zone of the Greenland ice sheet, a sampling programme was carried out by the authors in the 1985 field season as part of GGU's glacier-hydrological studies in West Greenland. The main efforts were concentrated in the ablation zone at Pâkitsup akuliarusersua about $40 \mathrm{~km}$ north-east of Jakobshavn/Ilulissat (fig. 1), where glacier-hydrological investigations have been carried out by GGU since 1982 (Thomsen, 1983). More than 700 ice and water samples were collected from 13 different locations. The samples comprise winter snow, collected on 9 May at seven sites along the GGU ablation profile covering an elevation interval of $250-900 \mathrm{~m}$, and samples of surface ice and meltwater collected along the same profile during the period $25 \mathrm{July}-7$ August at 12 sites in the elevation range 250 $1100 \mathrm{~m}$. At two locations (elevations 250 and $870 \mathrm{~m}$ ) $2.5 \mathrm{~m}$ ice cores were drilled to see to what extent the original seasonal variation in $\delta{ }^{18} \mathrm{O}$ would still be preserved in the ice of the ablation zone. Further detailed sampling of the surface ice at 2 and $5 \mathrm{~m}$ intervals was performed along a profile transverse to the ice margin south of lake 326 to a distance of $1.2 \mathrm{~km}$ from the ice edge (fig. 1). Moreover, some 100 samples were collected at nine different locations from the margin and drainage basin of Jakobshavn Isbræ with assistance from a field 


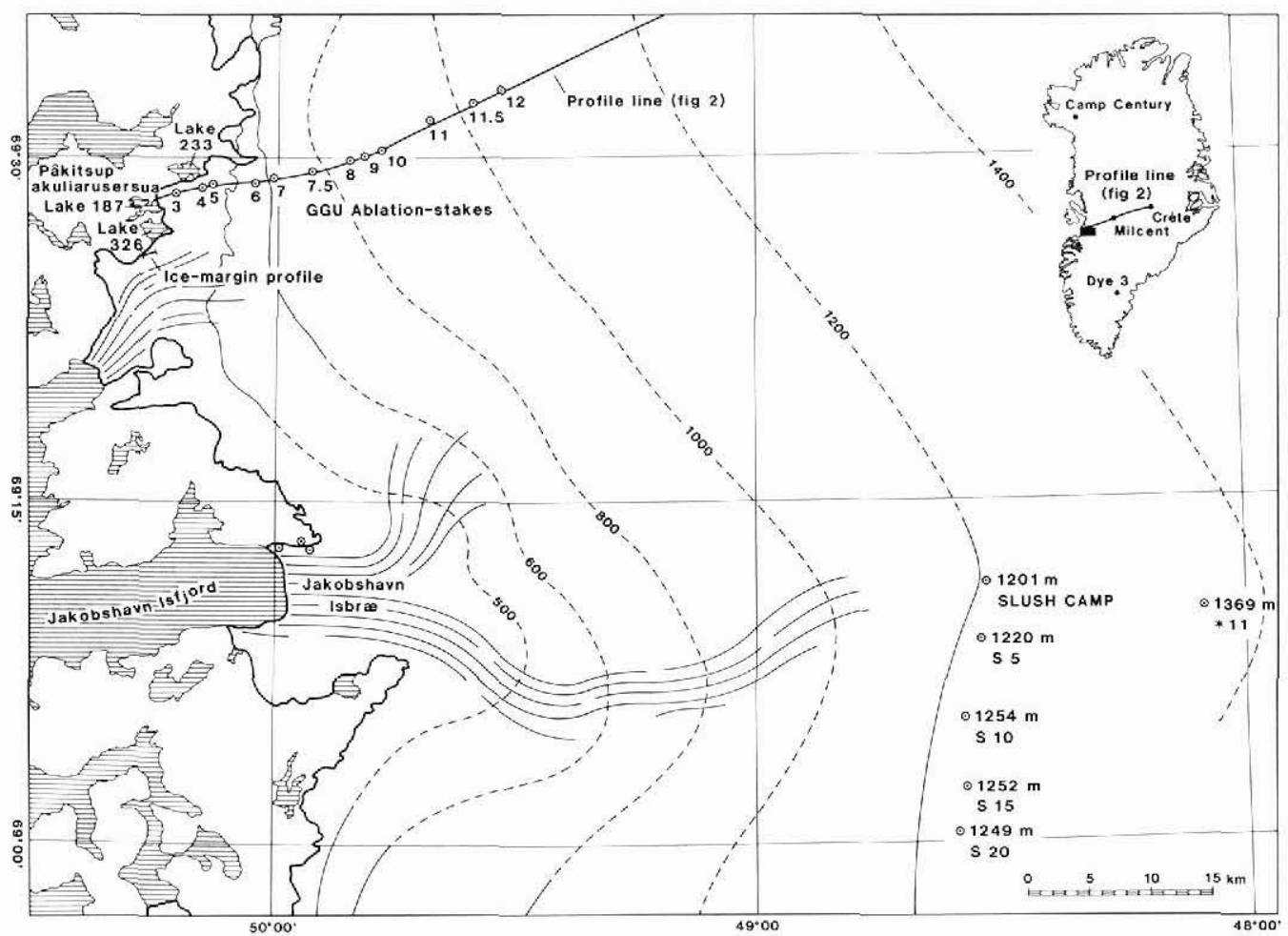

Fig. 1. Drainage basins at Pâkitsup akuliarusersua and Jakobshavn Isbræ. Locations for collection of ice and water samples are indicated. Positions of the sites in the Jakobshavn Isbræ drainage basin were supplied by Keith Echelmeyer, University of Alaska. The position of the profile shown in fig. 2 is also indicated.

party of the University of Alaska who were studying the dynamics of this large ice stream. In North Greenland about 50 samples were collected from the ice-sheet margin in Warming Land and about 10 samples from the margin of Flade Isblink, a local ice cap in eastern North Greenland.

The samples are being analysed for $\delta^{18} \mathrm{O}$ at the Geophysical Institute, University of Copenhagen. At the time of writing, about half the samples have been analysed. The results obtained so far show that isotope studies of the ice-sheet margin are useful in various fields:

(1) Isotope variations in the melt water runoff from the ice sheet can be helpful in the delineation of drainage basins on the ice sheet.

(2) By linking locations with the same observed isotope ratio in the accumulation and ablation zones of the ice sheet, information is obtained about ice-sheet dynamics.

(3) Isotope profiles from the outermost kilometre of the ice-sheet margin provide palaeoclimatic records dating back into the Wisconsinian.

(4) Different kinds of ice (local superimposed ice, regelation ice, etc.) can be distinguished by their isotopic ratios. 


\section{$\delta{ }^{18} \mathrm{O}$ elevation relationship}

Stable isotope analysis of surface snow and firn samples from the accumulation zone of the Greenland ice sheet has shown that the ${ }^{18} \mathrm{O} /{ }^{16} \mathrm{O}$ ratio $\left(\delta{ }^{18} \mathrm{O}\right)$ displays a systematic spatial variation over the ice-sheet surface, reflecting the variation in mean annual temperature (Dansgaard et al., 1973). This causes a positive trend of $\delta{ }^{18} \mathrm{O}$ from the high, cold, central regions of the accumulation zone towards the lower, warmer areas near the equilibrium line. In the ablation zone along the margin of the ice sheet, the ice, originally deposited as snow in the inland accumulation zone, reappears at the surface (fig. 2). The nearer to the ice divide the snow was originally deposited, the closer to the ice margin the corresponding ice will resurface, and the older it will be. Therefore, the isotopic composition of the ice in the ablation area will also display a large spatial variation, reflecting the corresponding variation in the deposition area. This is illustrated in fig. 2 and further in fig. 3 where $\delta{ }^{18} \mathrm{O}$ values of the samples collected in the study area are plotted against elevation. The data group around two straight lines: $\delta{ }^{18} \mathrm{O}$ values from the accumulation area and from winter snow samples collected in the ablation zone define one line with the equation:

$$
\delta_{\text {snow }}=-15.1-0.0057 \mathrm{E} \%
$$

where $\mathbf{E}=$ elevation in metres.

Another line is defined by the $\delta{ }^{18} \mathrm{O}$ values from ice samples in the ablation zone. This line has the equation:

$$
\delta_{\text {ice }}=-33.6+0.0113 \mathrm{E} \%
$$

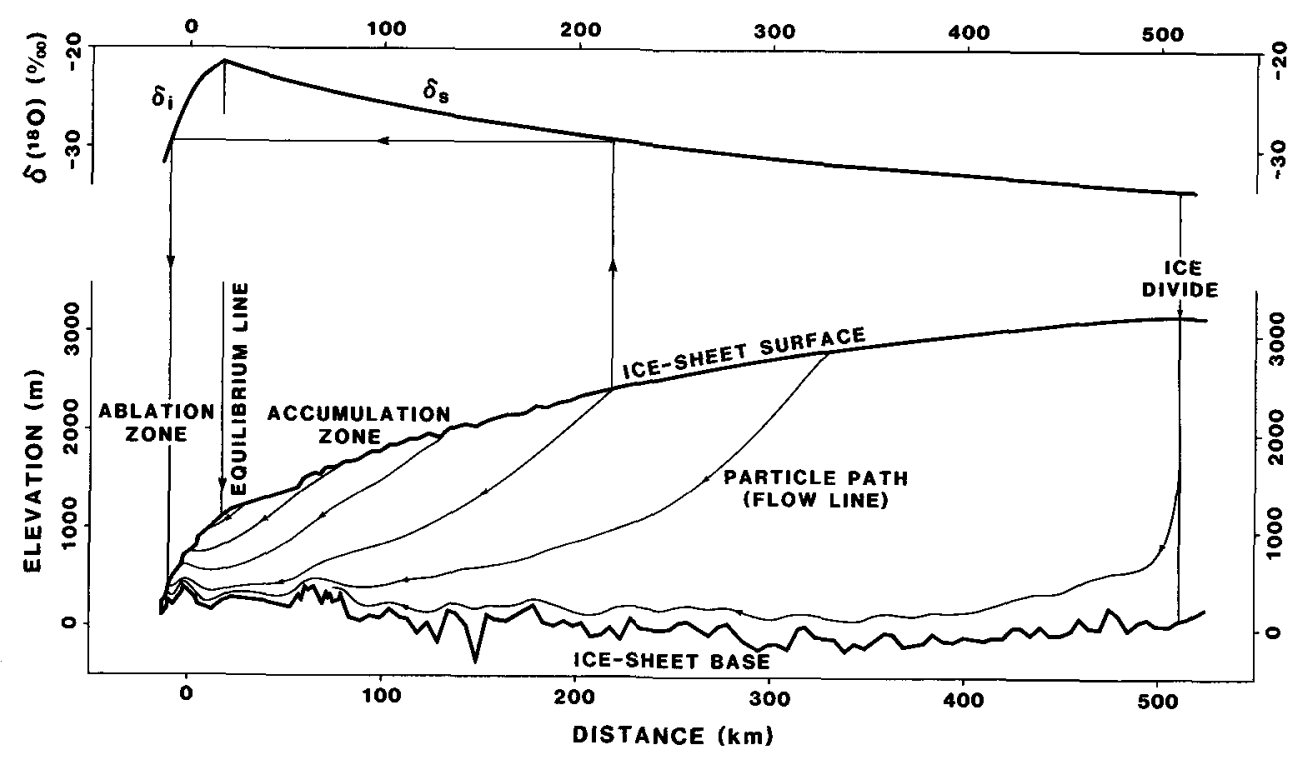

Fig. 2. Cross-section of the Greenland ice sheet along the profile line shown on the insert of fig. 1. Particle paths (flow-lines) are indicated, connecting points in the accumulation and ablation zone with same observed $\delta{ }^{18} \mathrm{O}$ values. The $\delta{ }^{18} \mathrm{O}$ distribution in the surface snow of the accumulation zone is based on data from Dansgaard et al. (1973). 


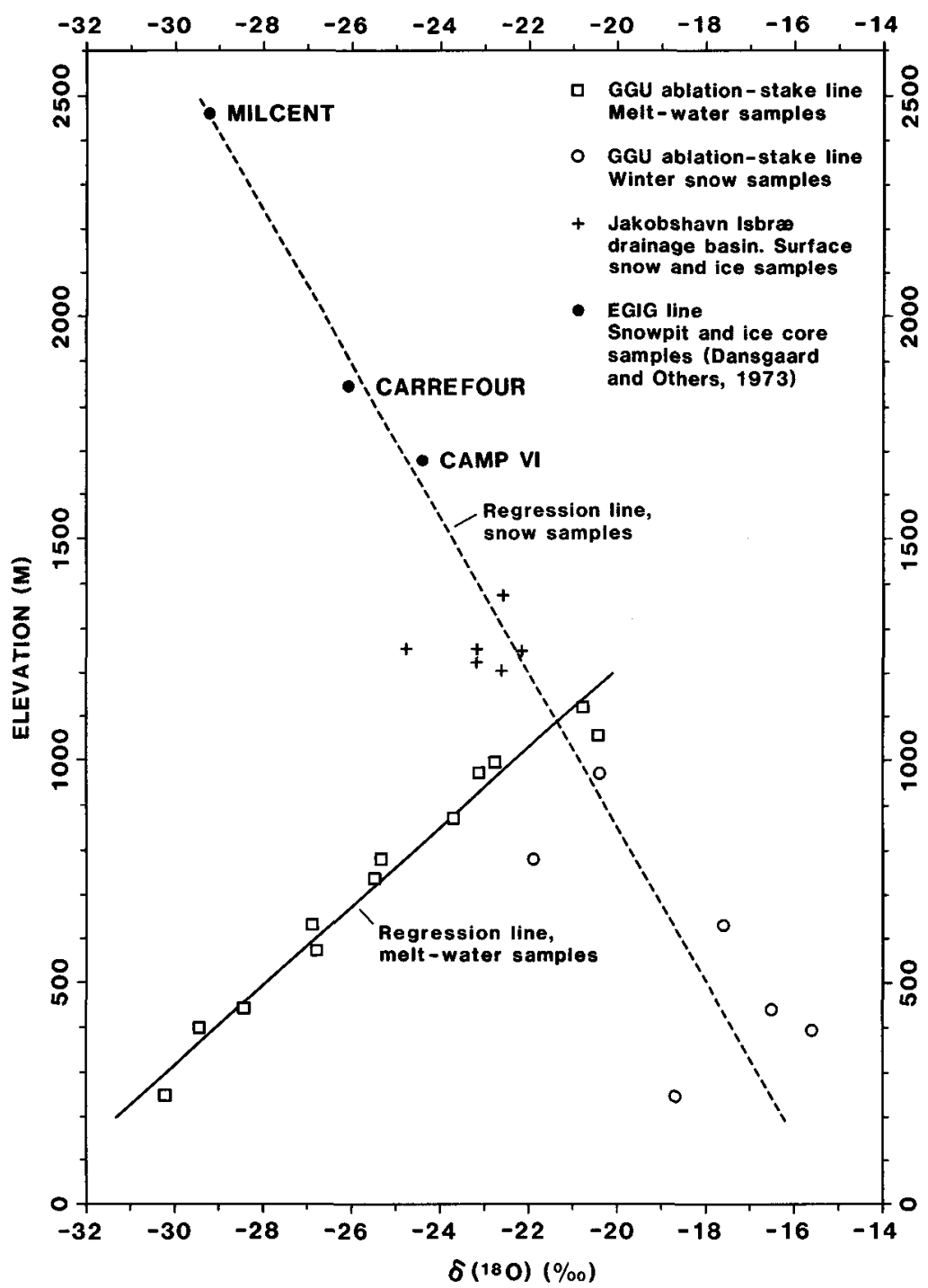

Fig. 3, $\delta{ }^{18} \mathrm{O}$ in surface ice and snow samples from the Greenland ice-sheet sector draining to Pâkitsup akuliarusersua, plotted versus elevation.

The intersection of the two lines determines the elevation of the equilibrium line to be around $1100 \mathrm{~m}$ in agreement with direct observations in the field (Thomsen \& Reeh, this report).

\section{Simulation of the $\delta{ }^{18} \mathrm{O}$ variation in the runoff}

The large spatial $\delta{ }^{18} \mathrm{O}$ variation on the ice-sheet surface suggests that $\delta{ }^{18} \mathrm{O}$ can be used as a natural tracer. To illustrate this possibility, a simple model has been designed to simulate the $\delta{ }^{18} \mathrm{O}$ variation of the meltwater runoff from the ice sheet. 


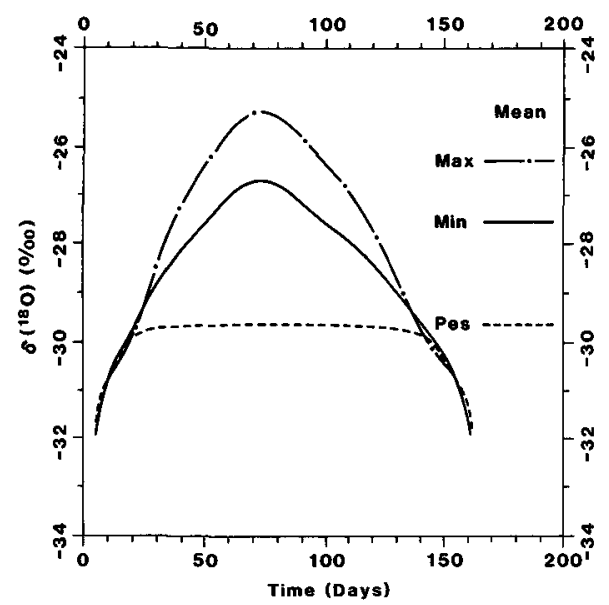

Fig. 4. Simulated $\delta{ }^{18} \mathrm{O}$ variation in the meltwater influx to lake 187. Max, Min, and Pes refer to the maximum and minimum estimates of the drainagebasin area given by Thomsen (1984) and the pessimistic estimate given by Thomsen (1985).

The model uses as input the elevation distributions of ice-sheet area, melt rate, and $\delta{ }^{18} \mathrm{O}$. Also the elevation of the 'runoff line' as a function of time through the melt season is required. Fig. 4 shows the results of three different simulations of the $\delta{ }^{18} \mathrm{O}$ variation of the meltwater influx to lake 187. Melt rates, $\delta{ }^{18} \mathrm{O}$ elevation relationship and the variation of the runoff line elevation with time are unchanged from one simulation to another, whereas three different elevation distributions of the ice-sheet area have been applied, i.e. the maximum and minimum estimates of Thomsen (1984) and the pessimistic estimate of Thomsen (1985).

As appears from fig. 4, the corresponding time variations of $\delta{ }^{18} \mathrm{O}$ are very different. Even the mean $\delta$ values over the melt season representing the isotopic composition of the water of lake 187 are significantly different. This indicates that monitoring the $\delta{ }^{18} \mathrm{O}$ variation in the melt water during the melt season may be helpful in the delineation of drainage basins on the ice sheet.

To fully utilize the method, however, the meltwater should be collected before it is mixed up in ice-marginal lakes. Obviously this is a problem at Pâkitsup akuliarusersua, where practically speaking all meltwater from the ice sheet runs directly into such lakes. To solve this problem, further investigations are needed, involving detailed stream flow and isotope studies in the lakes and the supra-glacial rivers.

\section{Linking points in the accumulation and ablation zones}

As illustrated in fig. 2 another application of $\delta^{18} \mathrm{O}$ as a natural tracer is to link points in the accumulation and ablation zones of the ice sheet with the same observed $\delta{ }^{18} \mathrm{O}$ value and thereby locate the start and end points of particle paths (flow lines). This information can be used to check (calibrate) ice-dynamic models for the ice margin, such as that of Reeh (1983).

Ice samples were collected at two profiles on the margin of Jakobshavn Isbra. Isotope analyses of these samples give generally higher $\delta{ }^{18} \mathrm{O}$ values in the down-glacier profile than in the up-glacier profile. This is contrary to the expected trend (fig. 2), and may be taken as an indication of complex, presumably non-stationary, flow conditions in the marginal zone of the ice stream. It also suggests that more detailed isotope studies can contribute to a better understanding of ice stream dynamics by distinguishing and locating the origin of the different types of ice composing the ice stream. 


\section{Ice-age isotopic record}

A $\delta{ }^{18} \mathrm{O}$ record from the outermost $1.2 \mathrm{~km}$ of the ice margin was obtained from the location shown in fig. 1. A detailed discussion of this profile and similar profiles obtained from the ice-sheet margin in North Greenland will be given elsewhere. Here we shall merely remark that the Holocene/Wisconsinian transition is found about $850 \mathrm{~m}$ from the ice margin, and that the corresponding $\delta{ }^{18} \mathrm{O}$ shift is about 6-8\%, similar to the shift measured on the deep ice core from Dye 3, but significantly less than the shift of 11-12\% found in the Camp Century record (Dansgaard et al., 1985). It should also be noticed that some $\delta$ variations in the Wisconsinian have apparently been preserved in the ice margin isotopic record. Nevertheless, the continuity of the record must be questioned because of the presence of numerous shear zones visible on the ice surface.

\section{Distinguishing different kinds of ice}

The outermost $230 \mathrm{~m}$ of the isotopic profile is different from the rest of the profile. The 30 m closest to the ice margin display $\delta{ }^{18} \mathrm{O}$ values around $-20 \%$. These rather high values are taken as evidence that the corresponding ice originates from local wind-drift snow, accumulated along the ice margin during the winter and transformed into superimposed ice during the summer melt-season. Samples of local isolated ice firn patches give $\delta{ }^{18} \mathrm{O}$ values similar to those referred to above from the very ice margin. Contrary to the outermost $30 \mathrm{~m}$ of the ice sheet which displays a moraine-free, light coloured ice surface, the adjoining $200 \mathrm{~m}$ are almost completely covered by a surface-moraine layer of varying thickness. The underlying ice which has a blackish appearance is remarkably homogeneous in respect of isotopic composition. This supports the interpretation that this ice is regelation ice formed by refreezing of meltwater at the base of the ice sheet. The measured $\delta{ }^{18} \mathrm{O}$ values around $-36 \%$ are rather low and suggest that the origin of the meltwater is mainly basal ice of Wisconsinian age.

A similar sequence of ice-types has been described by Hooke (1973) for the margin of Barnes Ice Cap in the Canadian Arctic.

Acknowledgements. Niels Henriksen (GGU) collected ice samples in Warming Land, North Greenland, and Håkansson and others collected samples from Flade Isblink, northern East Greenland. Henrik B. Clausen, Geophysical Institute, University of Copenhagen arranged the isotope analyses of the samples.

\section{References}

Dansgaard, W., Johnsen, S. J., Clausen, H. B., \& Gundestrup, N. 1973: Stable isotope glaciology. Meddr Grønland 197(2), 53 pp.

Dansgaard, W., Clausen, H. B., Gundestrup, N., Johnsen, S. J., \& Rygner, C. 1985: Dating and climatic interpretation of two deep ice cores. In Langway, C. C. Jr., Oeschger, H. \& Dansgaard, W. (edit.) Greenland ice core: geophysics, geochemistry, and the environment. Geophys. Monogr. 33, $71-76$.

Hooke, R. LeB. 1973: Flow near the margin of the Barnes Ice Cap, and the development of ice-cored moraines. Bull. geol. Soc. Amer. 84, 3929-3948.

Reeh, N. 1983: Ikke-stationær beregningsmodel for Indlandsisens randzone. Grønlands geol. Unders. Gletscher-hydrol. Meddr 83/7, 81 pp. 
Thomsen, H. H. 1983: Glaciologiske undersøgelser ved Pâkitsup ilordlia 1982. Ilulissat/Jakobshavn. Grønlands geol. Unders. Gletscher-hydrol. Meddr 83/3, 24 pp.

Thomsen, H. H. 1984: Glaciologiske undersøgelser i Disko Bugt området 1983. Grønlands geol. Unders. Gletscher-hydrol. Meddr 83/8, 24 pp.

Thomsen, H. H. 1985: Arbejdsnotat vedrørende afgrænsning af dræningsarealer ved Paakitsup Akuliarusersua, Jakobshavn. Unpublished internal report, Grønlands geol. Unders., 4 pp.

\title{
Geophysical investigations at the Inland Ice margin of the Pâkitsoq basin, central West Greenland
}

\author{
Leif Thorning, Henrik Højmark Thomsen and Egon Hansen
}

In recent years much effort has been directed towards investigation of the margin of the Inland Ice in connection with possible development of hydropower. The thickness of the ice and thus the subglacial relief has been difficult to determine. Electromagnetic reflection (EMR) techniques have been used over large parts of the Inland Ice with considerable success, but have so far not produced good results in the marginal areas of the Inland Ice. This note reports the successful application of EMR techniques to an area of the Inland Ice adjacent to the Pâkitsoq basin near Jakobshavn, central West Greenland, together with a ground magnetic survey over a smaller part of the area. The field areas are shown in fig 1 . The field work was carried out by LT and EH during a five week period in July-August 1985.

\section{Helicopter-borne EMR survey}

The original plans for the summer's EMR work called for a number of experiments to be carried out by a group from the University of Münster, West Germany, and were designed to explain why previous EMR measurements at the ice margin did not give good results. The Münster group were unable to come to Greenland, and in the spring of 1985 an alternative programme was decided upon to be carried out by GGU. The instrumentation used in 1984 without obtaining any results (Thomsen \& Madsen, 1985) was improved by the use of a new antenna, a two element fed cylindrical parabola installed in a helicopter rather than a fixedwing aircraft. The construction of this antenna was carried out at the Electromagnetics Institute, Technical University of Denmark. The characteristics of the instrumentation are given in Table 1.

The instruments could easily be installed in the back of the helicopter while still leaving room for a technician. The antenna was suspended between the floats of the helicopter (fig. 2). Plans to use another $60 \mathrm{Mhz}$ antenna were abandoned for flight safety reasons.

The first experimental tests of the improved radar equipment were so encouraging that it was decided to carry out a proper survey, and subsequently the lines shown in fig. 3 were acquired. The helicopter was a Glace Jet Ranger (OY-HBF) with floats, manned with a navigator (LT) and a technician (EH). The tests had shown the altitude above the ice surface to be a decisive factor for the penetration of the radar, and thus the measurements were carried 